\title{
Assessment of Applicability of Satellite-Derived Ocean Color Data for Studying Variability of Total Suspended Matter in the Surface Layer of the Deep Part of the Black Sea
}

\author{
A. S. Kukushkin*, V. V. Suslin \\ Marine Hydrophysical Institute of RAS, Sevastopol, Russian Federation \\ *kukushkinas@mail.ru
}

\begin{abstract}
Purpose. Studies of spatial-temporal variability of total suspended matter are necessary for understanding the biochemical processes which form and support stable functioning of a marine ecosystem. The aim of the work is to assess applicability of satellite data for studying total suspended matter variability in the surface layer of the deep part of the Black Sea.

Methods and Results. Application of the regression analysis yielded the linear regression equations that unite the in situ measurements of the total suspended matter concentrations in the surface layer in the northeastern (June, 2005-2015) and western (November, 2016, 2017 and December, 2017) deep sea areas, and the regional satellite products (the particulate backscattering coefficient, the absorption coefficient of colored detrital matter and the chlorophyll $a$ concentration). Based on the measured and calculated data arrays, the maps of the total suspended matter concentrations in the surface layer of the northeastern Black Sea were constructed. The interannual changes in the in situ measured concentrations of the total suspended and lithogenic matters, as well as in the quasi-synchronous satellite regional products (the light absorption coefficient of colored detrital matter at $490 \mathrm{~nm}$ and the particulate backscattering coefficient at $555 \mathrm{~nm}$ ) in June, 2005-2015 were considered. High total suspended matter concentrations were noted in 2012, just when extreme growth of the coccolithophorid population was observed in the Black Sea. The correlation coefficients were used to evaluate whether the relation between the total suspended matter concentration and the individual analyzed parameters was fast.

Conclusions. Spatial distributions of the measured and calculated total suspended matter contents showed satisfactory agreement. In course of the whole observation period, difference between the values of the measured and calculated total suspended matter concentrations was on average 6-23\%. Possibility of application of the satellite-derived ocean color data for studying spatialtemporal variability of the total suspended matter content is shown.
\end{abstract}

Keywords: Black Sea, total suspended matter, MODIS, particulate backscattering coefficient, light absorption coefficient, regression, correlation.

Acknowledgments: the research was carried out within the framework of the state task on theme No. 0827-2018-0001 "Fundamental studies of interaction processes in the ocean-atmosphere system conditioning regional spatial-temporal variability of natural environment and climate".

For citation: Kukushkin, A.S. and Suslin, V.V., 2020. Assessment of Applicability of SatelliteDerived Ocean Color Data for Studying Variability of Total Suspended Matter in the Surface Layer of the Deep Part of the Black Sea. Physical Oceanography, [e-journal] 27(5), pp. 547-556. doi:10.22449/1573-160X-2020-5-547-556

DOI: 10.22449/1573-160X-2020-5-547-556

(C) A. S. Kukushkin, V. V. Suslin, 2020

(C) Physical Oceanography, 2020

Introduction

Studies of the spatiotemporal variability of the total suspended matter (TSM) composition, consisting of organic and mineral fractions, are necessary to understand the biochemical processes that form and maintain the stable functioning 
of the marine ecosystem [1-4], as well as to study the processes of modern sedimentation [5].

The TSM composition in the upper sea layer is formed due to the inflow of organic and mineral substances from following external sources (allochthonous suspended matter): river, terrigenous and industrial and domestic wastewater, coastal abrasion and aeolian suspension. Along with external sources, biological processes of phytoplankton and bacterioplankton development, dying away and biochemical transformation of play an important role in the TSM structure formation (especially in deep sea areas).

According to the results of a few measurements of the TSM content in the upper layer of the Black Sea in the 1960-1970s [6-8] the ideas on the vertical structure and composition of TSM in summer were obtained. In 1978-1995 based on the results of experimental studies of the suspended organic matter content, the spatiotemporal variability of its components concentration and their relationship in the surface and photosynthesis layer were analyzed $[3,9,10]$. In $[9,11]$, the contribution of various sources (biogenic and terrigenous ones) to the TSM field formation was also estimated.

In the 2000s at the Institute of Oceanology of RAS active comprehensive studies of the TSM content and its vertical flow in the coastal and deep-water regions of the northeastern sea part, summarized in [12], strated. As a result, seasonal TSM content changes were revealed. In the deep-water sea part, they mainly consisted of the organic fraction, which depended on the species composition of phytoplankton.

Such studies are often characterized by the labor consuming nature of obtaining data on the TSM concentration of (water sampling with bathometers, their filtration, determination of composition, etc.) and the significant time spent on areal surveys to estimate the spatial TSM distribution. In recent decades, along with ship measurements, methods of remote sensing of the sea surface began to be used to assess the bioproductivity of certain regions of the World Ocean, including the Black Sea $[13,14]$, the suspended organic matter content $[15,16]$ and the TSM concentration [17-20].

The present paper is aimed to estimate the applicability of satellite data to study the variability of the TSM content in the surface layer of the deep-water part of the Black Sea.

\section{Materials and methods}

The data from ship measurements of the TSM content and its mineral fraction (lithogenic substance) obtained in the surface layer $(0-5 \mathrm{~m})$ in the northeastern (June 2005-2015) and western (November 2015, 2016 and December 2017) deep-water parts of the Black Sea [12] is used in the present research. Seawater samples taken with bottles were filtered through Whatman $G F / F$ glass fiber filters with a pore size of $0.45 \mu \mathrm{m}$ calcined at $450{ }^{\circ} \mathrm{C}$. The TSM concentration was determined by the gravimetric method. The content of the lithogenic substance was calculated by the wet chemistry method [21].

The daily average data of the MODIS-Aqua and MODIS-Terra color scanners (URL: http://oceancolor.gsfc.nasa.gov/) was also used for the analysis. It included the index of light backscattering by suspension particles at a wavelength of $555 \mathrm{~nm}$ $\left(b_{\mathrm{bp}}\right)$, the absorption index of the colored dissolved organic matter and detritus at 
a wavelength of $490 \mathrm{~nm}\left(a_{\mathrm{CDM}}\right)$ (hereinafter referred to as scattering and absorption indices) and the chlorophyll $a\left(C_{\mathrm{chl}}\right)$ concentration, obtained simultaneously with the results of TSM measurements. Observational data from color scanners were processed using regional algorithms that take into account the characteristics of the Black Sea waters [22-24].

The relationship between the measured TSM concentration and the indicators of color scanners, obtained at the same time or with a difference of no more than two days, was estimated using linear regression equations between them [25]. The satellite data obtained in the sea areas with coordinates coinciding with the coordinates of ship measurement stations were averaged. The results of the regression analysis are shown in Table 1 . There, in addition to the free term of the regression equation $a$ and the regression coefficient $b$, the coefficients of determination $R^{2}$ and correlation $R$, the standard error $\sigma$ and the number of pairs of parameters $N$ are also presented.

Table 1

Parameters of the regression equations $(y=a x+b)$ connecting the total suspended matter concentration and the MODIS regional products: the scattering coefficient

$\left(b_{\mathrm{bp}}\right)$, the absorption coefficient $\left(a_{\mathrm{CDM}}\right)$ and the chlorophyll $a\left(C_{\mathrm{chl}}\right)$ concentration in the deep part of the Black Sea in 2005-2017

\begin{tabular}{|c|c|c|c|c|c|c|}
\hline Year & Month & $a$ & $b$ & $R / R^{2}$ & $\sigma$ & $N$ \\
\hline \multicolumn{7}{|c|}{$x=b_{\mathrm{bp}}$} \\
\hline $2005-2017$ & June & 125.0 & -0.150 & $0.73 / 0.53$ & 0.170 & 65 \\
\hline $2015-2016$ & November & 39.6 & -0.110 & 0.93/0.87 & 0.040 & 9 \\
\hline 2017 & December & 55.9 & -0.270 & $0.90 / 0.81$ & 0.024 & 6 \\
\hline \multicolumn{7}{|c|}{$x=a_{\mathrm{cdm}}$} \\
\hline $2005-2017$ & June & 16.5 & -0.190 & $0.85 / 0.73$ & 0.140 & 70 \\
\hline 2015-2016 & November & 6.8 & -0.120 & $0.88 / 0.78$ & 0.060 & 9 \\
\hline 2017 & December & 4.1 & -0.008 & $0.81 / 0.66$ & 0.032 & 6 \\
\hline \multicolumn{7}{|c|}{$x=C_{\text {chl }}$} \\
\hline $2005-2017$ & June & 4.25 & 0.070 & $0.73 / 0.53$ & 0.180 & 67 \\
\hline 2015-2016 & November & 0.58 & -0.170 & $0.96 / 0.93$ & 0.030 & 9 \\
\hline 2017 & December & 0.31 & -0.100 & $0.81 / 0.76$ & 0.026 & 6 \\
\hline
\end{tabular}


The relationship between some pairs of parameters from Table 1, as well as between the concentration of lithogenic matter and satellite indicators is shown in Fig. 1 and 2. To estimate the relationship between individual parameters, pair, multiple and partial correlation coefficients were also used [25]. The statistical significance of the calculated correlation coefficients was determined by the standard algorithm using the Student's $t$-test.
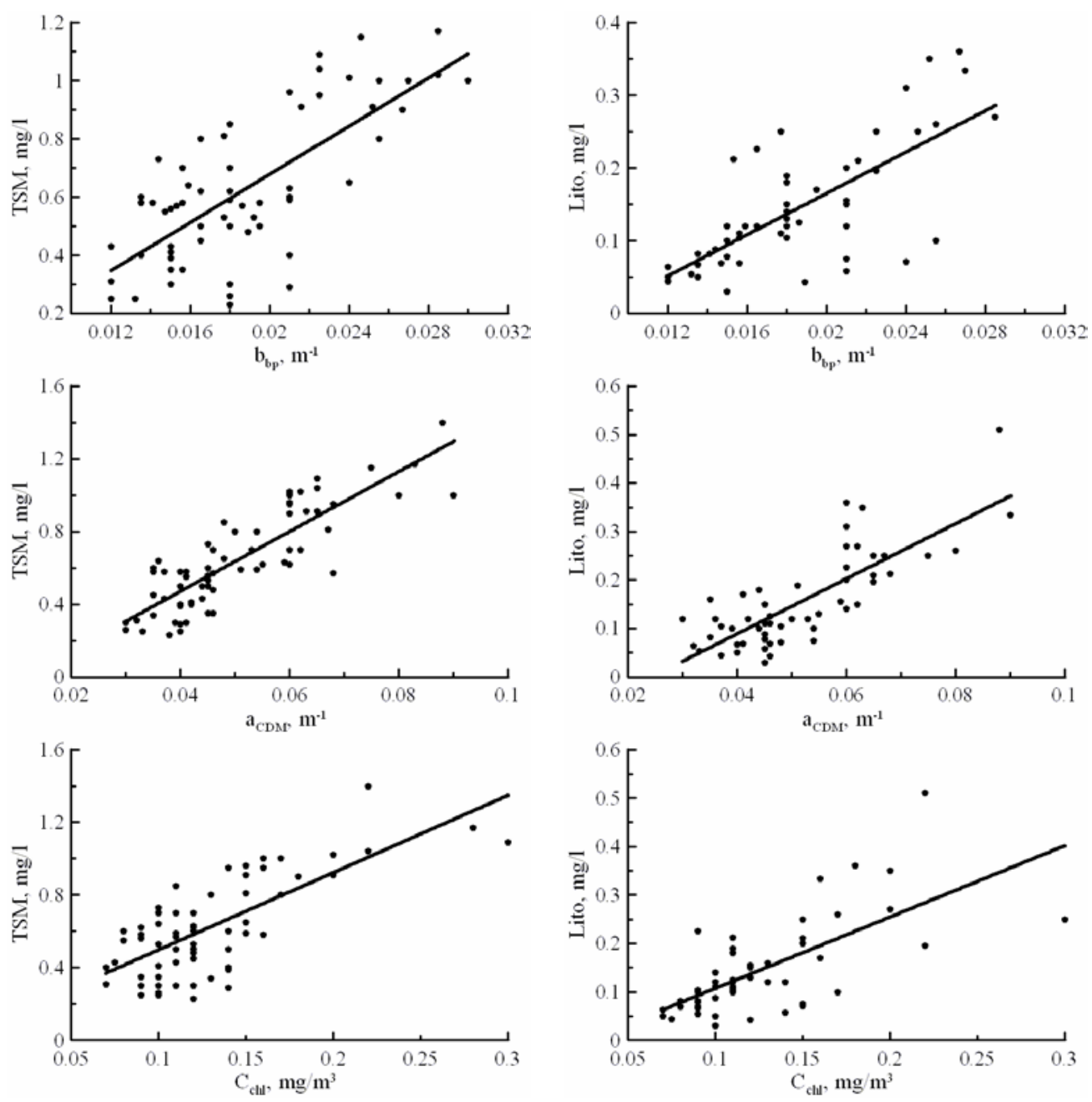

F i g. 1. Relation between the measured total suspended matter concentrations and the regional satellite products: particulate backscattering coefficient at $555 \mathrm{~nm}\left(b_{\mathrm{bp}}\right)$, the absorption coefficient of colored detrital matter at $490 \mathrm{~nm}$ $\left(a_{\mathrm{CDM}}\right)$ and the chlorophyll $a\left(C_{\mathrm{chl}}\right)$ concentration in the deep northeastern part of the Black Sea in June, 2005-2015

F i g. 2. Relation between the concentration of lithogenic substance (Lito) and the regional satellite products: the particulate backscattering coefficient at $555 \mathrm{~nm}\left(b_{\mathrm{bp}}\right)$, the absorption coefficient of colored detrital matter at $490 \mathrm{~nm}$ $\left(a_{\mathrm{CDM}}\right)$ and the chlorophyll $a\left(C_{\mathrm{chl}}\right)$ concentration in the deep northeastern part of the Black Sea in June, 2005-2015 


\section{Results}
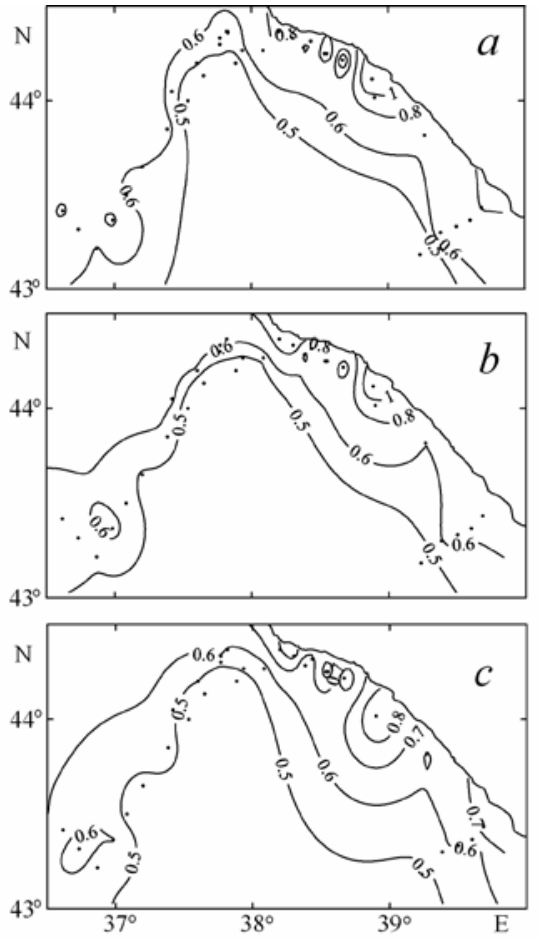

F i g. 3. Distribution of the measured $(a)$ and calculated by the particulate backscattering coefficient at $555 \mathrm{~nm}(b)$ and by the absorption coefficient of colored detrital matter at $490 \mathrm{~nm}$ (c) concentrations of total suspended matter in the northeastern part of the Black Sea in June, 2005-2015. Points denote stations
Using the regression equations bounding the TSM concentration and the values of the scattering and absorption indicators (Table 1) with the available satellite data array obtained during the period of ship measurements of the TSM content, makes it possible to calculate the TSM concentration at the points with the coordinates of the stations which these measurements were carried out at. Based on the measured and calculated data arrays, maps of the distribution of TSM concentrations were constructed (Fig. 3). In this case, the data obtained at stations located at depths of more than $300 \mathrm{~m}$ was used. Comparison of the distributions showed their satisfactory agreement. Increased TSM concentrations were recorded at alongshore stations close to the coast. With increasing distance from the coast and increasing depth, they also decreased.

A ten-year series (from 2005 to 2015, with the exception of 2008) of the measured TSM concentrations and lithogenic matter and satellite data ( $b_{\mathrm{bp}}, a_{\mathrm{CDM}}$ ) used for calculations makes it possible to trace their interannual changes.

Fig. 4 shows the interannual changes of the TSM and lithogenic matter concentrations and the values of the scattering and absorption indices in June obtained by data averaging for this month in each year at the stations located above depths over $500 \mathrm{~m}$. The character of the interannual variability of the analyzed parameters satisfactorily generally coincides. Increased values of the TSM and lithogenic matter concentrations were observed in 2011 and 2012. In these years, increased values of the absorption index were also noted. The maximum $b_{\mathrm{bp}}$ value was recorded only in 2011; in 2012, $b_{\text {bp }}$ was the minimum. It is known that in May and June 2012, an extreme bloom of coccolithophorids was observed in the Black Sea. 


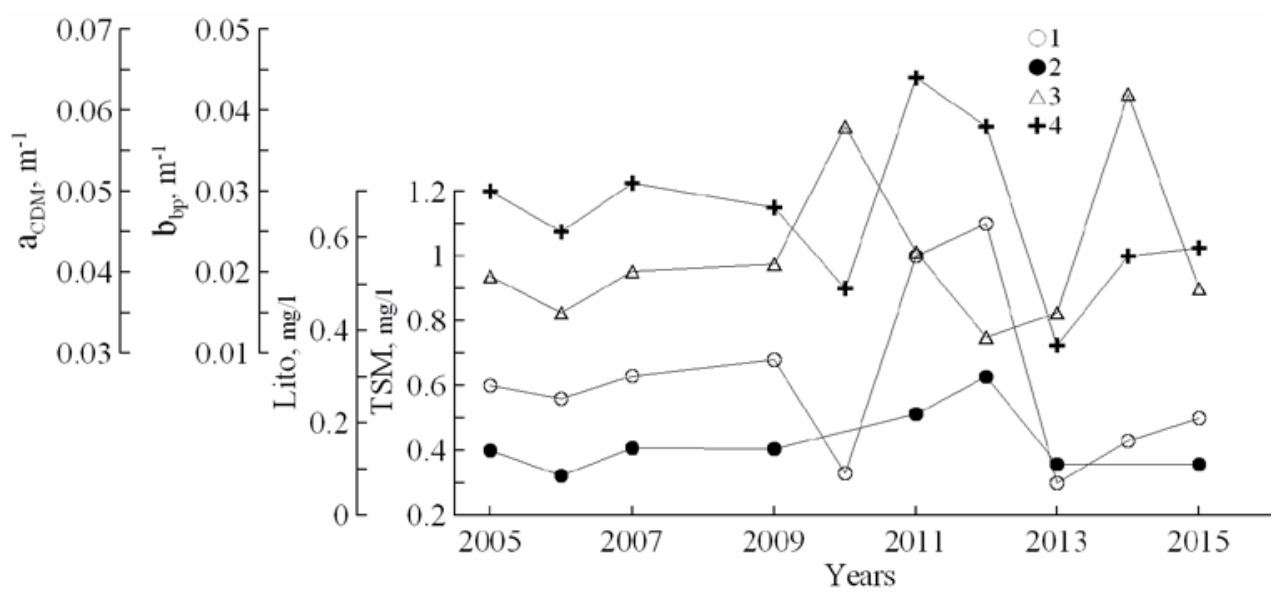

$\mathbf{F} \mathbf{i}$ g. 4. Interannual changes in the measured concentrations of total suspended matter (1) and lithogenic matter (2), and also in the regional MODIS products: the particulate backscattering coefficient (3) and the absorption coefficient of colored detrital matter (4) in the northeastern Black Sea in June, 2005-2015

The difference in the values of the measured and calculated TSM concentrations during the entire observation period ranged on average within $6-23 \%$. Their significant difference ( $\sim 60 \%$ ) in the case of calculating TSM by $b_{\text {bp }}$ was noted in 2012, when the measured TSM concentration was maximum, and in 2010 and 2013, when it was minimum. In part, this may be due to the discrepancy between the dates of ship and satellite observations.

The degree of neighboring relationship between the measured TSM concentration and the satellite data used to calculate its concentration can be estimated by pairwise and multiple correlation and determination coefficients (Table 2).

Table 2 data analysis showed that in all seasons (June, November and December) during the entire observation period, these coefficients are quite high, which indicates a close relationship between the TSM concentration and satellite data. At that, it is important to bear in mind that such a relationship for each pair of parameters is provided taking into account the relationship between all analyzed parameters. To determine the "pure" relationship between TSM and individual parameters while excluding the influence of the other two parameters on them, the partial coefficients of the $2^{\text {nd }}$ order (Table 3 ) is calculated. Table 3 data analysis 3 showed that in the northeastern sea region the closest relationship was observed between the TSM and lithogenic matter (the correlation coefficient is 0.78-0.83) concentrations and somewhat weaker - between the TSM and the scattering index (the correlation coefficient is $0.52-0.65$ ). This result is quite logical, since the light is scattered by the suspension particles and the lithogenic matter is included in its composition. In addition, the formation of the total suspended matter field in this area is influenced by shelf waters, in which the TSM content can be quite high (Fig. 3). 
Paired $(r)$ and multiple coefficients of correlation $(R)$ and determination $\left(R^{2}\right)$ between the total suspended matter concentration and the regional satellite products ( $b_{\mathrm{bp}}, a_{\mathrm{CDM}}, C_{\mathrm{chl}}$ ), and the lithogenic matter (Lito) concentration in the deep part of the Black Sea in 2005-2017

\begin{tabular}{|c|c|c|c|c|c|}
\hline Year & Month & $r_{12}$ & $r_{13}$ & $r_{23}$ & $R / R^{2}$ \\
\hline \multicolumn{6}{|c|}{$\begin{array}{l}\text { Connection of total suspended matter (TSM) concentration with } b_{\mathrm{bp}} \\
\text { and } a_{\mathrm{CDM}}\left(\mathrm{TSM}-b_{\mathrm{bp}}, a_{\mathrm{CDM}}\right)\end{array}$} \\
\hline 2005-2017 & June & 0.73 & 0.76 & 0.61 & $0.83 / 0.69$ \\
\hline 2015-2016 & November & 0.93 & 0.88 & 0.86 & $0.94 / 0.89$ \\
\hline 2017 & December & 0.93 & 0.81 & 0.67 & $0.96 / 0.93$ \\
\hline \multicolumn{6}{|c|}{$\mathrm{TSM}-b_{\mathrm{bp}}, C_{\mathrm{chl}}$} \\
\hline 2005-2017 & June & 0.73 & 0.73 & 0.79 & $0.77 / 0.6$ \\
\hline 2015-2016 & November & 0,93 & 0.97 & 0.90 & $0.98 / 0.96$ \\
\hline 2017 & December & 0,93 & 0.87 & 0.70 & $0.98 / 0.96$ \\
\hline \multicolumn{6}{|c|}{$\mathrm{TSM}-a_{\mathrm{CDM}}, C_{\mathrm{chl}}$} \\
\hline 2005-2017 & June & 0.76 & 0.73 & 0.62 & $0.83 / 0.69$ \\
\hline 2015-2016 & November & 0.88 & 0.97 & 0.83 & $0.93 / 0.96$ \\
\hline 2017 & December & 0.81 & 0.87 & 0.83 & $0.88 / 0.78$ \\
\hline \multicolumn{6}{|c|}{$\mathrm{TSM}-b_{\mathrm{bp}}$, Lito } \\
\hline $2005-2017$ & June & 0.73 & 0.82 & 0.72 & $0.84 / 0.71$ \\
\hline $2015-2016$ & November & 0.93 & 0.79 & 0.83 & $0.93 / 0.86$ \\
\hline 2017 & December & 0.93 & 0.76 & 0.82 & $0.93 / 0.86$ \\
\hline \multicolumn{6}{|c|}{$\mathrm{TSM}-a_{\mathrm{CDM}}$, Lito } \\
\hline 2005-2017 & June & 0.76 & 0.82 & 0.73 & $0.85 / 0.73$ \\
\hline 2015-2016 & November & 0.88 & 0.79 & 0.88 & $0.88 / 0.78$ \\
\hline 2017 & December & 0.81 & 0.76 & 0.77 & $0.84 / 0.70$ \\
\hline
\end{tabular}




\section{Particular second-order correlation coefficients between the total suspended matter concentration, the regional satellite products $\left(b_{\mathrm{bp}}, a_{\mathrm{CDM}}, C_{\mathrm{chl}}\right)$ and the lithogenic matter (Lito) concentration in the northeastern and western deep areas of the Black Sea}

\begin{tabular}{|c|c|c|c|c|c|c|c|}
\hline \multirow{2}{*}{ Area } & \multirow{2}{*}{ Parameters } & \multicolumn{6}{|c|}{$\begin{array}{l}\text { Correlation coefficients with the excluded from } \\
\text { the calculation of the indicators }\end{array}$} \\
\hline & & $\begin{array}{c}a_{\mathrm{CDM}}, \\
C_{\mathrm{chl}}\end{array}$ & $\begin{array}{c}a_{\mathrm{CDM}}, \\
\text { Lito }\end{array}$ & $\begin{array}{l}C_{\text {chl, }} \\
\text { Lito }\end{array}$ & $\begin{array}{l}b_{\mathrm{bp}} \\
C_{\mathrm{chl}}\end{array}$ & $\begin{array}{l}b_{\mathrm{bp}}, \\
\text { Lito }\end{array}$ & $\begin{array}{c}b_{\mathrm{bp}}, \\
a_{\mathrm{CDM}}\end{array}$ \\
\hline \multirow{4}{*}{ Northeastern } & $b_{\text {bp }}$ & 0.62 & 0.65 & 0.52 & - & - & - \\
\hline & $a_{\mathrm{CDM}}$ & - & - & -0.18 & 0.33 & -0.20 & - \\
\hline & $C_{\text {chl }}$ & - & 0.46 & - & - & -0.10 & 0.23 \\
\hline & Lito & 0.78 & - & - & 0.84 & - & 0.83 \\
\hline \multirow{4}{*}{ Western } & $b_{\mathrm{bp}}$ & 0.38 & 0.73 & 0.41 & - & - & - \\
\hline & $a_{\mathrm{CDM}}$ & - & - & 0.43 & 0.40 & 0.53 & - \\
\hline & $C_{\text {chl }}$ & - & 0.90 & - & - & 0.83 & 0.86 \\
\hline & Lito & 0.01 & - & - & 0.07 & - & -0.37 \\
\hline
\end{tabular}

In the western sea area, the closest relationship was noted between the TSM and concentrations (the correlation coefficient is 0.83-0.90). The relationship between TSM and scattering and absorption indices is somewhat weaker (on average, the correlation coefficient is 0.45-0.50). Lack of the relationship was noted between TSM and lithogenic material. These results of the analysis of the relationship are apparently associated with the seasonal variability of phytoplankton development and the conditions of the TSM field formation in the western sea area.

\section{Conclusion}

Using the obtained linear regression equations, the concentrations of total suspended matter TSM were calculated from satellite data (scattering and absorption indicators and chlorophyll $a$ concentration). The difference in the values of the measured and calculated TSM concentrations over the entire observation period was on average within 6-23\%. The comparison of the spatial distributions of the measured and calculated TSM concentrations in the northeastern deep-water part of the Black Sea showed their satisfactory agreement. Satisfactory agreement was also noted for interannual changes in the TSM and lithogenic matter concentration and in the scattering and absorption indices.

Using the calculated partial correlation coefficients, the tightness of the relationship between the TSM concentration and individual analyzed parameters was estimated. In the northeastern deep-water sea part in June 2005-2015 the closest relationship was obtained between the TSM and lithogenic matter concentrations and between the concentration of TSM and the scattering 
index, for which the correlation coefficient varied within $0.78-0.83$ and $0.52-0.65$, respectively. In the western area, the partial correlation coefficients between the TSM and chlorophyll $a$ concentrations, as well as between the concentration of TSM and the scattering and absorption indices, were $0.83-0.90$ and $0.45-0.50$, respectively.

The given examples of the calculated data application illustrate the possibility of using satellite data to study the spatiotemporal TSM variability.

\section{REFERENCES}

1. Romankevich, E.A., 1977. [Geochemistry of Organic Matter in the Ocean]. Moscow: Nauka, 256 p. (in Russian).

2. Alimov, A.F., 2000. [Elements of the Theory of Water Ecosystem Functioning]. Saint Petersburg: Nauka, 147 p. (in Russian).

3. Burlakova, Z.P., Eremeeva, L.V. and Konovalov, S.K., 2000. Seasonal and Spatial Variability of the Content of Suspended Organic Substances in the Active Layer of the Black Sea. Physical Oceanography, 10(5), pp. 419-454. https://doi.org/10.1007/BF02515365

4. Eremeev, V.N. and Konovalov, S.K., eds., 2012. [Stability and Evolution of Oceanological Characteristics of the Black Sea Ecosystem]. Sevastopol: ECOSI-Gidrofizika, 357 p. (in Russian).

5. Lisitsyn, A.P., 1991. [Processes of Terrigenous Sedimentation in the Seas and Oceans]. Moscow: Nauka, 270 p. (in Russian).

6. Emelianov, E.M., 1962. Some Data on the Suspended Matter in the Black and Mediterranean Seas. Okeanologia, 2(4), pp. 664-672 (in Russian).

7. Vityuk, D.M., 1975. [Suspended Matter and Its Components in the Black Sea]. Gidrobiologicheskiy Zhurnal, 11(1), pp. 12-18 (in Russian).

8. Trimonis, E.S. and Shimkus, K.M., 1976. Quantitative Distribution of Suspended Matter in the Black Sea. Okeanologia, 16(4), pp. 648-654 (in Russian).

9. Vostokov, S.V., 1997. Suspended Matter as an Index of Productivity in the Western Black Sea (Application for Productivity and Eutrophication Control). In: E. Özsoy and A. Mikaelyan, eds., 1997. Sensitivity to Change: Black Sea, Baltic Sea and Nord Sea. Dordrecht: Springer, pp. 211-221.

10. Kukushkin, A.S., 2014. Variability of Suspended Organic Matter in the Surface Layer of the Black Sea (Deep-Sea Areas). Oceanology, 54(5), pp. 606-617. https://doi.org/10.1134/S0001437014050099

11. Dimitrov, P.S., Stoyanov, A.S. and Shtereva, G.P., 1981. On the Distribution of Suspended Material in Western Part of the Black Sea-Water Area. Dokladi na Bolgarskata Akademiya na Naukite, 34(10), pp. 1429-1431.

12. Klyuvitkin, A.A., Kravchishina, M.D., Lisitzin, A.P., Demina, L.L., Dara, O.M., Novigatsky, A.N., Rusanov, I.I. and Solomatina, A.S., 2018. Vertical Fluxes of Dispersed Sedimentary Matter in the Deep-Water Part of the Black Sea. In: A. P. Lisitsyn, ed., 2018. The Black Sea System. Moscow: Scientific World, pp. 350-397. doi:10.29006/978-5-91522-473-4.2018 (in Russian).

13. Kopelevich, O.V., Burenkov, V.I., Ershova, S.V., Sheberstov, S.V. and Evdoshenko, M.A., 2004. Application of SeaWiFS Data for Studying Variability of Bio-Optical Characteristics in the Barents, Black and Caspian Seas. Deep Sea Research Part II: Topical Studies in Oceanography, 51(10-11), pp. 1063-1091. https://doi.org/10.1016/j.dsr2.2003.10.009

14. Finenko, Z.Z., Suslin, V.V. and Churilova, T.Ya., 2010. Estimation of Phytoplankton Productivity in the Black Sea Based on Satellite Data. Doklady Biological Sciences, 432(1), pp. 233-236. https://doi.org/10.1134/S0012496610030191

15. Kukushkin, A.S. and Parkhomenko, A.V., 2018. Evaluation of Applicability of the Satellite Data for Studying Suspended Organic Matter Variability in the Surface Layer of the Black Sea. Sovremennye Problemy Distantsionnogo Zondirovaniya Zemli iz Kosmosa, 15(1), pp. 195-205. doi:10.21046/2070-7401-2018-15-1-195-205 (in Russian). 
16. Kukushkin, A.S. and Parkhomenko, A.V., 2019. Variability of the Content of Suspended Organic Matter along the Southwestern Crimean Coast According to Ship and Satellite Observations. Sovremennye Problemy Distantsionnogo Zondirovaniya Zemli iz Kosmosa, 16(1), pp. 137-146. doi:10.21046/2070-7401-2019-16-1-137-146 (in Russian).

17. Vazyulya, S.V., Kopelevich, O.V., Sheberstov, S.V. and Artemiev, V.A., 2014. Satellite Estimation of the Coefficients of CDOM Absorption and Diffuse Attenuation in the White and Kara Seas. Sovremennye Problemy Distantsionnogo Zondirovaniya Zemli iz Kosmosa, 11(4), pp. 31-41 (in Russian).

18. Gordon, H.R., Boynton, G.C., Balch, W.M., Groom, S.B., Harbour, D.S. and Smyth, T.J., 2001. Retrieval of Coccolithophore Calcite Concentration from SeaWiFS Imagery. Geophysical Research Letters, 28(8), pp. 1587-1590. https://doi.org/10.1029/2000GL012025

19. Suetin, V.S. and Korolev, S.N., 2018. Estimating Specific Features of the Optical Property Variability in the Black Sea Waters Using the Data of SeaWiFS and MODIS Satellite Instruments. Physical Oceanography, 25(4), pp. 330-340. doi:10.22449/1573-160X-2018-4-330-340

20. Kremenchutskiy, D.A., Kubryakov, A.A., Zav’yalov, P.O., Konovalov, B.V., Stanichniy, S.V. and Aleskerova, A.A., 2014. Determination of the Suspended Matter Concentration in the Black Sea using to the Satellite MODIS Data. In: MHI, 2014. Ekologicheskaya Bezopasnost' Pribrezhnykh i Shel'fovykh Zon i Kompleksnoe Ispol'zovanie Resursov Shel'fa [Ecological Safety of Coastal and Shelf Zones and Comprehensive Use of Shelf Resources]. Sevastopol: ECOSI-Gidrofizika. Iss. 29, pp. 5-9 (in Russian).

21. Gel'man, E.M. and Starobina, I.Z., 1976. [Photometric Methods for the Determination of Major Elements in Ores, Rocks, and Minerals]. Moscow: GEOKhI AN SSSR, 69 p. (in Russian).

22. Suslin, V.V. and Churilova, T.Ya., 2016. A Regional Algorithm for Separating Light Absorption by Chlorophyll- $a$ and Coloured Detrital Matter in the Black Sea, Using 480-560 $\mathrm{nm}$ Bands from Ocean Colour Scanners. International Journal of Remote Sensing, 37(18), pp. 4380-4400. https://doi.org/10.1080/01431161.2016.1211350

23. Suslin, V., Pryahina, S., Churilova, T. and Slabakova, V., 2016. The Black Sea IOPs Based on SeaWiFS Data. In: SPIE, 2016. Proceedings of SPIE 10035, 22nd International Symposium on Atmospheric and Ocean Optics: Atmospheric Physics, 1003531. doi:10.1117/12.2248332

24. Suslin, V.V., Suetin, V.S., Korolev, S.N. and Kucheryavyi, A.A., 2007. Use of SeaWiFS Data to Estimate Water Optical Properties of the Black Sea. In: SPIE, 2007. Proceedings of SPIE 6615, Current Research on Remote Sensing, Laser Probing, and Imagery in Natural Waters, 661509. doi:10.1117/12.740445

25. Erenberg, A.M., 1981. [Analysis and Interpretation of Statistical Data]. Moscow: Finansy i statistika, 406 p. (in Russian).

About the authors:

Alexandr S. Kukushkin, Senior Research Associate, Marine Hydrophysical Institute of RAS (2 Kapitanskaya St., Sevastopol, Russian Federation, 299011), Ph. D. (Maths.-Phys.), ORCID ID: 0000-0003-4673-1004, Scopus Author ID: 57197414211, kukushkinas@mail.ru

Viacheslav V. Suslin, Leading Research Associate, Marine Hydrophysical Institute of RAS (2 Kapitanskaya St., Sevastopol, Russian Federation, 299011), Ph. D. (Maths.-Phys.), ORCID ID: 00000-0002-8627-7603, Scopus Author ID: 6603566261, slava.suslin@mhi-ras.ru

Contribution of the authors:

Alexandr S. Kukushkin - setting the aims and tasks of the work, assessing the relations between ship and satellite observations, analyzing the results and making conclusions

Viacheslav V. Suslin - preparation and processing of the satellite data, discussion of the research results

All the authors have read and approved the final manuscript.

The authors declare that they have no conflict of interest. 